\title{
Isolasi dan Karakterisasi Bakteri Asam Laktat (BAL) dari Ale-ale dan Cincalok
}

\author{
Anggia Nurhamidah $^{1}$, Warsidah $^{1 *}$, Nora Idiawati ${ }^{1}$ \\ 1 Program studi Ilmu Kelautan, FMIPA, Universitas Tanjunpura, Pontianak- \\ Indonesia \\ *Correspondence email: Warsidah \\ $\square$ warsidah@fmipa.untan.ac.id
}

\author{
Received:26 September 2019- Accepted: 2 October 2019 \\ Published: 31 October 2019 @ Author(s) 2019. This article is open access
}

\begin{abstract}
Ale-ale dan cincalok merupakan produk makanan khas Kalimantan Barat yang diolah melalui proses fermentasi secara alami melibatkan Bakteri Asam Laktat (BAL). BAL dikategorikan sebagai foodgrade microorganism karena bersifat non-patogen dan aman bagi manusia, juga mempunyai peranan penting dalam fermentasi makanan dalam pengaruh pengawetan dengan hasil peningkatan daya awet pada produk. Karakteristik BAL pada penelitian ini yaitu gram positif, katalase negatif, mampu memfermentasi glukosa, negatif indol, mampu menggunakan sitrat sebagai salah satu sumber karbon dan energi, non motil, memproduksi karbohidrat dengan cara fermentasi, tipe fermentasi heterofermentatif, tumbuh pada suhu 10 dan 37, dan tumbuh pada konsentrasi $\mathrm{NaCl} 4 \%$ dan $6,5 \%$. Genus BAL yang berhasil diisolasi dan diidentifikasi dari sampel ale-ale dan cincalok adalah Lactobacillus.
\end{abstract}

Keywords: Ale-ale, Bakteri asam laktat (BAL), Cincalok, Lactobacillus.

\section{Pendahuluan}

Ale-ale dan cincalok merupakan produk makanan khas Kalimantan Barat yang cukup populer. Cincalok dibuat dari fermentasi udang kecil, gula, dan garam yang disimpan dalam jangka waktu 3-7 hari (Nofianiani dan Ardiningsih, 2018). Sedangkan formulasi komposisi Ale-ale meliputi daging kerang ale-ale, gula, garam, dan bawang putih (Sari, 2012). Kedua produk tersebut diolah melalui proses fermentasi secara alami yang melibatkan mikroba. Salah satu mikroba yang berperan penting dalam proses fermentasi adalah Bakteri Asam Laktat (BAL).

BAL merupakan kelompok bakteri Gram positif, tidak berspora, berbentuk bulat atau batang, anaerob fakultatif, dan tidak motil
(Desniar, 2012). BAL memiliki peran penting dalam proses fermentasi dalam memberikan efek pengawetan terhadap makanan dalam menghambat mikroba patogen. Bakteri asam laktat dikategorikan sebagai foodgrade microorganism juga bersifat non patogen dan aman bagi manusia.

Berdasarkan hasil fermentasi yang diperoleh, BAL dibagi menjadi dua, yaitu kelompok homofermentatif dan kelompok heterofermentat if. Homofermentatif hanya menghasilkan asam laktat sebagai produk utama dari proses fermentasinya, dan menggunakan jalur Embden Meyerhof Pathnas (EMP) dalam proses fermentasinya (Purwoko, 2007). Sedangkan, kelompok heterofermentatif menghasilkan asam laktat,, COr2, dan etanol dari heksosa (Jay et al., 2005). Kelompok heterofermentatif 
memfermentasi glukosa melalui jalur fosfoketolase (Hidayah, 2006).

\section{Metode}

\subsection{Waktu dan tempat}

Penelitian dilaksanakan selama empat bulan, mulai Bulan Februari hingga bulan mei 2019. Sampel dibeli dari produsen produk pangan di kawasan pesisir Kabupaten Ketapang, Kalimantan Barat. Penelitian ini meliputi isolasi dan karakterisasi yang dilakukan di Laboratorium Bioteknologi Jurusan Kimia dan Laboratorium Mikrobiologi Jurusan Biologi Fakultas Matematika dan Ilmu Pengetahuan Alam Universitas Tanjungpura, Pontianak Kalimantan Barat.

\subsection{Prosedur kerja}

Prosedur penelitian ini dilakukan dengan tahap isolasi dan karakterisasi bakteri asam laktat untuk mengetahui genus dari bakteri tersebut yang meliputi isolasi, pewarnaan gram, uji katalase, uji biokimia dan uji fisiologis.

\subsubsection{Isolasi koloni BAL}

Sampel ale-ale dan cincalok sebanyak 5 gram dimasukkan ke dalam $45 \mathrm{~mL}$ media MRSB, kemudian diinkubasi pada suhu 37 ${ }^{\circ} \mathrm{C}$ selama 24 jam (Sari et al., 2013). Selanjutnya dilakukan pengenceran bertingkat hingga diperoleh pengenceran tertinggi yaitu 10-7 dengan cara $1 \mathrm{~mL}$ sampel dari media MRSB dimasukkan ke dalam tabung reaksi berisi $9 \mathrm{~mL}$ pepton water (Sari et al., 2013).

Setelah itu, kultur ditumbuhkan dengan menggunakan metode pour plate pada media MRSA (Inkubasi suhu $37{ }^{\circ} \mathrm{C}$ selama 48 jam) (Sari et al., 2013). Koloni BAL tunggal yang tumbuh dimurnikan kembali dengan cara menginokulasikan koloni ke dalam media MRSA secara gores (inkubasi suhu $37^{\circ} \mathrm{C}$ selama 48 jam) (Sari et al., 2013). Pengamatan morfologi koloni dilakukan setelah mendapatkan biakan murni. Pengamatan makroskopis meliputi bentuk, warna, tepian, dan elevasi koloni bakteri. Permukaaan koloni dapat dilihat dari samping, dan tepi koloni dapat dilihat dari atas cawan (Hadioetomo, 1993).

\subsubsection{Pewarnaan Gram}

Kaca objek yang digunakan untuk pewarnaan Gram disterilkan dengan alkohol $70 \%$. Isolat bakteri diambil 1 ose dan dioleskan di atas kaca objek, difiksasi beberapa kali pada Bunsen. Isolat bakteri ditetesi 2 tetes Kristal violet dan dibiarkan selama 1 menit. Isolat ditetesi iodin, dibiarkan selama 1 menit. Isolat bakteri ditetesi alkohol 96\% secara perlahan-lahan selama 30 detik. Isolat ditetesi safranin secara perlahan-lahan selama 30 detik. Isolat yang telah diwarnai selanjutnya diamati menggunakan mikroskop pada pembesaran 100x. Pengamatan meliputi warna dan bentuk sel bakteri. Bakteri Gram prositif ditandai dengan warna ungu karena mampu mengikat kristal violet. Bakteri Gram negatif ditandai dengan terbentuknya warna merah muda karena tidak mampu mengikat kristal violet dan hanya terwarnai oleh safranin (Ismail et al., 2017).

\subsubsection{Uji Katalase}

Uji katalase dilakukan dengan meneteskan $\mathrm{H} 2 \mathrm{O} 23 \%$ pada isolat BAL di atas kaca objek. Reaksi positif pada uji katalase ditandai dengan terbentuknya gelembung udara pada isolat setelah ditetesi $\mathrm{H} 2 \mathrm{O} 23 \%$. Terbentuk gelembung udara pada isolat tersebut menunjukkan adanya enzim katalase yang dihasilkan oleh bakteri yang dapat mengubah $\mathrm{H} 2 \mathrm{O} 2$ menjadi $\mathrm{H} 2 \mathrm{O}$ dan $\mathrm{O} 2$ (Hadioetomo, 1993 dalam Ismail et al., 2017).

\subsubsection{Uji Biokimia}

Uji TSIA (Triple Sugar Iron Agar), isolat BAL diinokulasi pada media TSIA dengan cara ditusuk tegak lurus pada bagian butt dengan cara zig zag pada bagian slant. Selanjutnya, inkubasi isolat pada suhu $37{ }^{\circ} \mathrm{C}$ selama 24 jam (Ismail et al., 2017).

Uji Indol, isolat BAL diinokulasi pada media pepton water kemudian inkubasi selama 24 jam pada suhu $37{ }^{\circ} \mathrm{C}$ setelah diinkubasi, selanjutnya isolat di tetesi reagen kovac's sebanyak 5 tetes (Ismail et al., 2017).

Uji Oksidasi Fermentasi (O/F), isolat BAL diinokulasi pada 2 tabung yang berisi media $\mathrm{O} / \mathrm{F}$. Tabung 1 ditetesi paraffin, dan tabung kedua tanpa paraffin. Inkubasi selama 48 jam pada suhu 37. Uji tipe fermentasi, isolat BAL diinokulasi pada media MRSB dalam tabung reaksi yang telah berisi tabung durham. Selanjutnya, inkubasi selama 48 jam pada suhu $37^{\circ} \mathrm{C}$ (Ismail et al., 2017).

Uji motilitas, isolat BAL diinokulasi secara vertical pada media SIM. Selanjutnya, inkubasi selama 48 jam pada suhu $37{ }^{\circ} \mathrm{C}$ (Harley, 2005 dalam Ismail et al., 2017). 
Uji MR-VP, isolat BAL diinokulasi ke media MR-VP, inkubasi pada suhu $37{ }^{\circ} \mathrm{C}$ selama 48 jam. Pengamatan uji MR dilakukan dengan menambahkan tiga tetes reagen methylred ke dalam media (Hadioetomo, 1993). Uji VP dilakukan dengan menambahkan tiga tetes $\mathrm{KOH} 3 \%$ dan lima tetes alfanaftol, lalu dikocok selama 30 detik (Ismail et al., 2017).

\subsubsection{Pewarnaan Fisiologis}

Uji ketahanan suhu dilakukan dengan menumbuhkan Isolat BAL pada suhu yang berbeda dengan menggunakan media MRS Broth kemudian diinkubasi selama 48 jam pada suhu $10{ }^{\circ} \mathrm{C}$ dan $37{ }^{\circ} \mathrm{C}$ (Anastiawan, 2014). Uji ketahanan garam, isolat BAL diinokulasi pada media MRSB yang telah ditambahkan $\mathrm{NaCl}$ dengan konsentrasi 4\% dan $6,5 \%$. Inkubasi pada suhu $37{ }^{\circ} \mathrm{C}$ selama 24 jam (Thakkar et al., 2015 dalam Ismail et al., 2017).

\section{Hasil dan Pembahasan}

Uji ketahanan suhu dilakukan dengan menumbuhkan Isolat BAL pada suhu yang berbeda dengan menggunakan media MRS Broth kemudian diinkubasi selama 48 jam pada suhu $10{ }^{\circ} \mathrm{C}$ dan $37{ }^{\circ} \mathrm{C}$ (Anastiawan, 2014). Uji ketahanan garam, isolat $\mathrm{BAL}$ diinokulasi pada media MRSB yang telah ditambahkan $\mathrm{NaCl}$ dengan konsentrasi 4\% dan $6,5 \%$. Inkubasi pada suhu $37{ }^{\circ} \mathrm{C}$ selama 24 jam (Thakkar et al., 2015 dalam Ismail et al., 2017). susu. Hal tersebut mempertegas bahwa dari keseluruhan isolat merupakan BAL. Koloni tunggal dari isolat bakteri asam laktat kemudian dimurnikan untuk dilakukan uji karakterisasi.

Pewarnaan Gram dilakukan untuk mengetahui jenis sel isolat bakteri, untuk menentukan jenis bakteri berdasarkan perbedaan struktur dinding sel. Hasil pewarnaan Gram yang dilakukan Putri et al. (2014) menunjukkan BAL yang diisolasi dari fermentasi rusip ikan teri merupakan bakteri Gram positif, hal tersebut ditunjukkan dengan terbentuknya warna ungu pada sel bakteri serta memiliki bentuk bulat dan batang. Berdasarkan hasil pengamatan uji pewarnaan Gram pada penelitian ini, yaitu isolat BAL memiliki bentuk morfologi sel batang dan terbentuk warna ungu pada sel. BAL pada penelitian ini termasuk ke dalam kelompok bakteri Gram positif, dan isolat tersebut merupakan genus Lactobacillus. Mengacu pada buku Bergey's Manual of Determinative
Bacteriology, BAL memiliki karakteristik Gram positif.

Hasil uji katalase pada kedua isolat bakteri menunjukan katalase negatif, hal tersebut ditunjukkan dengan tidak adanya gelembung gas yang berisi oksigen ketika isolat ditetesi dengan larutan $\mathrm{H} 2 \mathrm{O} 2$. Romadhon et al. (2012) melakukan uji katalase isolat BAL yang diisolasi dari usus udang produk hasil perikanan dengan hasil katalase negatif pada semua isolat BAL. Hasil uji TSIA pada penelitian ini yaitu terbentuk perubahan warna media menjadi merah pada bagian slant dan kuning pada bagian butt. Hal tersebut menunjukkan bahwa BAL mampu memfermentasi glukosa (Ismail et al., 2017). Hasil penelitian Nursyirwani et al. (2011) BAL yang diisolasi dari usus ikan kerapu macan menunjukkan reaksi asam pada uji TSIA yang dilihat dari perubahan warna media menjadi berwarna kuning pada bagian slant dan butt.

Uji sitrat digunakan untuk melihat kemampuan bakteri menggunakan sitrat sebagai salah satu sumber karbon dan energi. Bakteri mampu menggunakan sitrat, maka asam akan dihilangkan dari media biakan, sehingga menyebabkan peningkatan $\mathrm{pH}$ dan mengubah warna media dari hijau menjadi biru (Pattuju et al., 2014). Uji penggunaan sitrat pada isolat BAL menggunakan media SCA (simmons citrate agar) menunjukkan hasil positif, hal tersebut ditunjukkan dengan adanya perubahan warna media SCA dari hijau menjadi biru. Uji sitrat menunjukkan hasil positif jika terjadi perubahan warna pada media dari hijau menjadi biru (Anggraini et al., 2016). Hal tersebut dapat disimpulkan bahwa BAL mampu menggunakan sitrat sebagai salah satu sumber karbon dan energi.

Uji oksidasi fermentasi bertujuan untuk mengetahui sifat oksidasi fermentasi suatu bakteri terhadap glukosa. Bakteri oksidatif akan memanfaatkan oksigen dalam menghasilkan $\mathrm{CO} 2$ dan $\mathrm{H} 2 \mathrm{O}$, bakteri bersifat oksidatif warna pada media uji berubah menjadi warna biru, dan apabila bakteri bersifat fermentatif media uji $\mathrm{O} / \mathrm{F}$ berubah warna menjadi warna kuning (Benson, 2001). Uji oksidasi fermentasi pada isolat BAL ini menunjukkan bahwa isolat hanya mampu melakukan metabolisme karbohidrat secara fermentasi, hal tersebut ditandai dengan terjadinya perubahan warna media yang ditambahkan paraffin dan tanpa paraffin dari hijau menjadi kuning. 
Tabel 1. Hasil Isolasi dan Identifikasi Bakteri Asam Laktat (BAL)

\begin{tabular}{|c|c|c|c|c|c|}
\hline No & Perlakuan & $\begin{array}{c}\text { BAL. } \\
\text { AL1 }\end{array}$ & $\begin{array}{l}\text { BAL. } \\
\text { AL2 }\end{array}$ & $\begin{array}{l}\text { BAL. } \\
\text { CN1 }\end{array}$ & $\begin{array}{l}\text { BAL. } \\
\text { CN2 }\end{array}$ \\
\hline \multirow[t]{5}{*}{1} & Morfologi Koloni BAL & & & & \\
\hline & Bentuk bulat & + & + & + & + \\
\hline & Tepian utuh (entire) & + & + & + & + \\
\hline & Elevasi cembung & + & + & + & + \\
\hline & Warna putih/krem & putih & putih & krem & putih \\
\hline 2 & Pewarnaan Gram $(+)$ & + & + & + & + \\
\hline 3 & Katalase & - & - & - & - \\
\hline \multirow[t]{12}{*}{4} & Biokimia & & & & \\
\hline & Asam Sulfida $\left(\mathrm{H}_{2} \mathrm{~S}\right) /$ TSIA & $\mathrm{m} / \mathrm{k}$ & $\mathrm{m} / \mathrm{k}$ & $\mathrm{m} / \mathrm{k}$ & $\mathrm{m} / \mathrm{k}$ \\
\hline & Indol & - & - & - & - \\
\hline & Sitrat & + & + & + & + \\
\hline & Motilitas & - & - & - & - \\
\hline & Oksidasi Fermentasi & + & + & + & + \\
\hline & Methylred dan vogesprokauer (MR-VP) & & & & \\
\hline & Methylred (MR) & + & + & + & + \\
\hline & Vogesprokauer (VP) & - & - & - & - \\
\hline & Tipe Fermentasi & & & & \\
\hline & Homofermentatif & - & - & - & - \\
\hline & Heterofermentatif & + & + & + & + \\
\hline \multirow[t]{7}{*}{5} & Fisiologis & & & & \\
\hline & Ketahanan Suhu & & & & \\
\hline & $10^{\circ} \mathrm{C}$ & + & + & - & + \\
\hline & $37{ }^{\circ} \mathrm{C}$ & + & + & + & + \\
\hline & Ketahanan Garam & & & & \\
\hline & $4 \%$ & + & + & + & + \\
\hline & $6.5 \%$ & + & + & + & + \\
\hline
\end{tabular}

Ketengan: (+) Terjadi reaksi menghasilkan positif; (-) Tidak terjadi reaksi; (m/k) slant merah/butt kuning; (BAL.AL) Bakteri asam laktat dari ale-ale; (BAL.CN) Bakteri asam laktat dari cincalok.

Tipe fermentasi BAL pada penelitian ini yaitu heterofermentatif, hal tersebut sesuai dengan adanya gelembung gas dalam tabung durham yang terperangkap setelah diinkubasi selama 48 jam. Menurut Ismail et al. (2017) bakteri yang menampung gas dalam tabung durham dinyatakan sebagai kelompok bakteri asam laktat kelompok heterofermentatif.

Uji methylred dilakukan untuk menentukan adanya fermentasi asam campuran. Beberapa bakteri memfermentasi glukosa dan menghasilkan berbagai produk yang bersifat asam sehingga akan menurunkan $\mathrm{pH}$ media pertumbuhannya menjadi 5 atau menjadi lebih rendah. Penambahan indikator $\mathrm{pH}$ methyl red dapat menunjukan adanya perubahan $\mathrm{pH}$ menjadi asam. bila terjadi fermentasi asam campuran, indikator akan berwarna merah sedangkan bila tidak terjadi fermentasi asam campuran maka indikator akan berwarna kuning (Lay, 1994). Isolat BAL pada penelitian ini menunjukkan BAL mampu menggunakan asam campuran, hal tersebut ditunjukkan dengan adanya perubahan warna media menjadi merah. Hal tersebut sama dengan hasil penelitian Ismail et al. (2017) yaoitu semua isolat Lactobacillus yang diperoleh dari fermentasi biji kakao (Theobroma cacao L.) menunjukkan positif methylred yang artinya semua BAL yang diperoleh mampu memfermentasi asam campuran.

Uji vogesproskauer dilakukan untuk mengetahui kemampuan BAL dalam membentuk asetil metil karbinol (asetoin) dari hasil fermentasi glukosa. Media yang telah ditambahkan indikator napthol 5\% dan $\mathrm{KOH} 40 \%$ akan mengalami perubahan media dari kuning menjadi merah, yang berarti bakteri dapat membentuk asetoin, apabila hasil negatif maka warna media tidak berubah (Ulfa et al., 2016). Seluruh isolat BAL yang diperoleh dari cincalok dan ale-ale menunjukkan warna media yang tidak beruabh, yang berarti BAL ini tidak membentuk asetil metil karbonil (asetoin) dari hasil fermentasi glukosa. Hal tersebut hampir sama dengan penelitian Ismail et al. 
(2017) yaitu semua isolat Lactobacillus (BAL) yang diperoleh dari fermentasi biji kakao menunjukkan negatif vogersproskauer. Uji pembentukan Indol dilakukan untuk menunjukkan adanya indol dan triptofan. Hasil uji indol pada penelitian ini menunjukkan negatif indol karena tidak terbentuk cincin berwarna merah dalam media.

Uji motilitas isolat BAL pada penelitian ini menunjukkan non motil. Hasil tersebut dapat dilihat dari tidak adanya pertumbuhan bakteri yang menyebar pada media SIM, melainkan hanya tumbuh pada bekas tusukan jarum inokulum saja. Ulfa et al. (2016) menyatakan bahwa hasil positif motil pada bakteri ditunjukkan dengan adanya pertumbuhan bakkteri yang menyebar di sekitar tusukan. Penelitian Amaliah (2016) menunjukkan uji motilitas yang dilakukan pada isolat BAL yang diisolasi dari limbah cair rendaman kacang kedelai menghasilkan negatif motil atau non motil.

Hasil uji ketahanan BAL terhadap perbedaan suhu $10 \quad{ }^{\circ} \mathrm{C}$ dan $37{ }^{\circ} \mathrm{C}$ menunjukkan $\mathrm{BAL}$ dapat tumbuh dengan baik, hal tersebut ditunjukkan dengan adanya kekeruhan pada media setelah diinkubasi. Hasil penelitian Menconi et al. (2014) didapat 2 isolat BAL tumbuh pada suhu 15 ${ }^{\circ} \mathrm{C}$ dan $45^{\circ} \mathrm{C}$ yang diinkubasi selama 24 jam.

Hasil pengamatan keempat isolat yang telah diinkubasi selama 48 jam pada konsentrasi $\mathrm{NaCl}$ yang berbeda (4\% dan $6,5 \%$ ) dapat tumbuh dengan baik, hal tersebut ditunjukkan dengan adanya kekeruhan pada media setelah diinkubasi. Isolat BAL yang tumbuh merupakan bakteri Lactobacillus. Hasil penelitian Ismail et al. (2017) didapat 2 isolat BAL Lactobacillus tumbuh pada konsentrasi $\mathrm{NaCl} 4 \%$ dan $6,5 \%$ yang diinkubasi selama 24 jam.

\section{Kesimpulan}

Karakteristik BAL pada penelitian ini yaitu merupakan bakteri Gram positif, katalase negatif, mampu memfermentasi glukosa, negatif indol, mampu menggunakan sitrat sebagai salah satu sumber karbon dan energi, non motil, memproduksi karbohidrat dengan cara fermentasi, tipe ferentasi heterofermentatif, tumbuh pada suhu $10{ }^{\circ} \mathrm{C}$ dan $37{ }^{\circ} \mathrm{C}$, dan dapat tumbuh pada konsentrasi $\mathrm{NaCl} 4 \%$ dan 6,5\%. Sehingga dapat disimpulkan BAL tersebut merupakan genus Lactobacillus.

\section{Ucapan Terima Kasih}

Penulis mengucapkan terimakasih kepada Kementrian Riset, Teknologi dan Pendidikan Tinggi Indonesia atas program beasiswa Bidikmisi dari pemerintah yang telah mendanai penelitian ini.

\section{Daftar Pustaka}

Amaliah, Nur Z.Z., 2016, Isolasi dan karrakterisasi Bakteri Asam Laktat dari Limbah Cair Rendaman Kacang Kedelai, Fakultas Kedokteran Dan Ilmu Kesehatan, Uin Syarif Hidayatullah Jakarta, Jakarta (Skripsi)

Anastiawan, 2014, Isolasi dan Karakterisasi Bakteri Probiotik yang Berasal dari Usus Itik Pedaging Anas domesticus, Universitas Hasanudin Makassar, Makassar (Skripsi).

Anggraini, R.; Aliza, D. dan Mellisa, S., 2016, Identifikasi Bakteri Aeromonas Hydrophila Dengan Uji Mikrobiologi Pada Ikan Lele Dumbo (Clarias gariepinus) yang Dibudidayakan di Kecamatan Baitussalam Kabupaten Aceh Besar, J. Ilmi. Mhs. Kelautan Perikanan Unsyiah, 1(2):270-286.

Benson, 2001, Microbiological Application Lab Manual. $8^{\text {th }}$ Ed. Mc Graw Hill Companies, New York.

Chandra, J.I.; Zahiruddin, W. dan Desniar., 2007, Isolasi dan Karakterisasi Bakteri Asam Laktat dari Produk Bekasam Ikan Bandeng, J. Teknol. Hasil. Perikanan., 10 (2).

Desniar.; Rusmana, I.; Suwanto, A. dan Mubarik, N.R., 2012, Senyawa antimikroba yang dihasilkan oleh bakteri asam laktat asal bekasam, J. Akuatika, 3(2): 135-145

Fardiaz, S., 1993, Analisis Mikrobiologi Pangan, PT. Raja Grafindo Persada, Jakarta

Hadioetomo, R.S., 1993, Mikrobiologi Dasar Dalam Praktek, Teknik dan Prosedur Dasar Laboratorium, PT. Gramedia, Jakarta.

Harley, John P., 2005, Laboratory Exercises in Microbiology, Sixth Edition, The McGraw-Hill Companies, New York

Hidayat, 2006, Mikrobiologi Industri, Yogyakarta: C.V Andi Offset

Ismail, Y. S.; Yulvizar, C. dan Putriani, 2017, Isolasi, Karakterisasi dan Uji Aktivitas Antimikroba Bakteri Asam Laktat dari Fermentasi Biji Kakao (Theobroma cacao L.), J. Bioleuser, 1(2); 45-53

Jay, J.M.; J. Loessner. Annd D.A. Golden, 2005, Modern food microbioloy, $7^{\text {th }}$ ed. Springer Science, New York: $790 \mathrm{hlm}$.

Jaya, F. dan Didik, H., 2009, Pengaruh Substitusi Susu Sapi dengan Susu Kedelai serta Besarnya Konsentrasi Penambahan Ekstrak Nenas (Ananas Comosus) Terhadap Kualitas Fisik dan Kimia Keju Cottage, J. Ilm. Tekno Hasil Ternak. 4(1): 46-54. 
Lay, B., 1994, Analisis Mikrobia di Laboratorium, Manajemen PT Grafindo Persada, Jakarta.

Menconi, A.; Kallapura, G.; Latorre, J. D.,; Morgan, M. J.; Pumford, N. R.; Hargis, B. M. and Tellez, G., 2014, Identification and Characterization of Lactic Acid Bacteria in a Commercial Probiotic Culture, J. BMFH, 33(1).

Nofiani, R. and Ardiningsih, P., 2018, Physicochemical And Microbiological Profiles of Commercial Cincalok from West Kalimantan, J. PHPI. 21(2):243-249.

Nursyirwani.; Asmara, W.; Wahyuni, A.E.T.H. dan Triyanto, 2011, isolasi Bakteri Asam Laktat dari Usus Ikan Kerapu Macan (Epinephelus fuscoguttatus) dan Potensinya sebagai Antivibrio, J. Ilm. Kel., 16 (2): 70-77.

Pattuju, S.; M. Fatimawali. dan Manampiring, A., 2014, Identifikasi Bakteri Resisten Merkuri pada Urine, Feses, dan Kalkulus Gigi pada Individu di Kecamatan Malalayang, Manado, Sulawesi Utara, J. e-Biomedik.।Purwoko, Tjahjadi, 2007, Fisiologi Mikroba, Jakarta: Bumi Aksara.

Putri, D.M.; Budiharjo, A. dan Kusdiyantini, E., 2014, Isolasi, Karakterisasi Bakteri Asam Laktat, dan Analisis Proksimat dari Pangan Fermentasi Rusip Ikan Teri (Stolephorus Sp.), J. Biologi., 3 (2): 11-19.

Romadhon.; Subagiyo. dan Margino, S., 2012, Isolasi dan Karakterisasi Bakteri Asam Laktat dari Usus Udang Penghasil Bakteriosin Sebagai Agen Antibakteria pada Produk-Produk Hasil Perikanan, J. Saint. Perikanan., 8 (1).

Sari, R. A.; Nofiani, R. dan Ardiningsih, P., 2012, Karakterisasi Bakteri Asam Laktat Genus Leuconostoc dari Pekasam Ale-ale Hasil Formulasi Skala Laboratorium, J. Kimia Khatulistiwa, 1(1): 14-20.

Sari, Yuni N.M.; Sumaryati, S. dan Jamsari, 2013, Isolasi, Karakterisasi dan identifikasi DNA Bakteri Asam Laktat (BAL) yang berpotensi sebagai Antimikroba dari Fermentasi Markisa Kuning (Passiflora edulis var. flavicarpa), $J$. Kim. Univ. Andalas.,2(2)

Thakkar, Pooja, H.A. Modi. and J.B., Prajapati., 2015, Isolation, Characterization and Safety Assessment of Lactic Acid Bacterial Isolats from Fermented Food Products, J. Int. Cur. Micro Applied Science , 4(4): 713-725

Ulfa, A.; Suarsini, E. dan Irawati, Mimien H., 2016, Isolasi dan Uji Sensitivitas Merkuri pada Bakteri dari Limbah Penambangan Emas di SekotongBarat Kabupaten Lombok Barat: Penelitian Pendahuluan, Proceeding Biology Education Conference, 3(1): 793-799. 